\title{
Substitution of Kasila Group Basalt with the Archean Man Gneiss in Asphalt and Hydraulic Concrete Mix Design (Sierra Leone)
}

\author{
Ibrahima Sow ${ }^{1}$, Ibrahima Khalil Cisse ${ }^{2 *}$ \\ ${ }^{1}$ Doctoral School of the University of Thies, Senegal \& Comapagnie Sahélienned' Entreprises, Dakar, Senegal \\ ${ }^{2}$ Laboratoire de Matériaux, Mécanique et Hydraulique (LMMH), Ecole Polytechnique de thiès, Thiès, Senegal \\ Email: ibrahima.sow3@univ-thies.sn, ${ }^{*}$ ikcisse2002@yahoo.fr
}

How to cite this paper: Sow, I. and Cisse, I.K. (2019) Substitution of Kasila Group Basalt with the Archean Man Gneiss in Asphalt and Hydraulic Concrete Mix Design (Sierra Leone). Open Journal of Civil Engineering, 9, 291-310.

https://doi.org/10.4236/ojce.2019.94021

Received: August 30, 2019

Accepted: October 26, 2019

Published: October 29, 2019

Copyright (c) 2019 by author(s) and Scientific Research Publishing Inc. This work is licensed under the Creative Commons Attribution International License (CC BY 4.0).

http://creativecommons.org/licenses/by/4.0/

\begin{abstract}
The study of the performances of the Archean of Man gneiss aggregates with the addition of filler to replace the basalt of Kasila group in the asphalt and concrete mix design of southern Sierra Leone is presented in this document. The goal is to compare the results of the asphalt and concrete mix design with gneiss and basalt aggregate. The applied methods and design used are 1) Volumetric design and Marshall method for the asphalt, 2) French Dreux-Gorisse Method for the concrete. We added 2\% of gneissic filler and $2 \%$ portland cement type $42.5 \mathrm{R}$ to the asphalt hot mix with the gneiss aggregates to follow the criteria variation. The Marshall, the diametric compression and the Duriez tests require us to perform four different types of mix design. The four mix designs meet the requirements but F2 and F4 give the best mechanical properties. F2 (gneiss $+2 \%$ filler) and F4 (basalt) have many similarities from which we can conclude their interchangeability. F2 gives 5255 of optimal bitumen content. In regards to hydraulic concrete, the results of the compressive strength test (cement content $350 \mathrm{~kg}$ CMI $42.5 \mathrm{R} / \mathrm{m}^{3}$ ) with the gneiss and basalt aggregates are respectively $40 \mathrm{MPa}$ and $45 \mathrm{MPa}$ at 28 days curing: these values are greater than $35 \mathrm{MPa}$ required by the technical specifications. The use of the Super Fluid ${ }^{\oplus}$ Thermoplast 120 admixture, to increase the concrete compressive strength, is justified by the requirement of a minimum of $80 \% \mathrm{Rc}_{28}$ at 24 hours. For both types of concrete, we have at 24 hours, 34 and $35 \mathrm{MPa}$ which are higher than the minimum of $32 \mathrm{MPa}$ (in 24 h). These results meet the requirements of the technical specifications.
\end{abstract}

\section{Keywords}

Gneiss, Basalt, Asphalt Concrete, Hydraulic Concrete, Marshall, Duriez, Diametric Compression 


\section{Introduction}

A good road network with good infrastructure is essential to create a suitable environment for economic development. In West Africa, some economically strategic areas are still isolated due to poor road conditions.

As part of the Mano River cooperation between Liberia, Sierra Leone and Guinea, it is planned to link Monrovia (Liberia) and Conakry (Guinea) via BO (Southern Sierra Leone).

In order to connect Liberia and southern Sierra Leone, the European Development Fund has financed the Bandajuma-Mano River section, which is $103 \mathrm{~km}$ long.

However, the Bandajuma-Mano river project crosses the gneiss of the Archean Domain of Man [1].

It is in this context that research is being conducted on gneiss as a substitute for the long-used basalt.

To meet the objectives of this study, the following will be carried out:

a) The geological overview will provide a presentation of the local geology of southern Sierra Leone.

b) Asphalt mix Design in addition to the Marshall tests, the water sensitivity will be evaluated by the Duriez test. Using a mathematical approach, elastic modulus values will be calculated to assess the behavior of asphalt mix design with the compaction level.

c) The Concrete mix design with gneiss aggregates will allow the determination of its compatibility with Portland cement and its performance compared with basalt aggregates.

\section{Materials}

\subsection{Petrography}

Figure 1 shows the eight groups of geological units in Sierra Leone.

The archean crystalline basement of Sierra Leone consists of two groups of acidic rocks. These are older gneisses and younger granitoid. In the Archaean Craton of West Africa, there are at least three different age groups of older gneisses with ages of crystallization of U-Pb zircon of 3.5, 3.3 - 3.1 and 3.0 - 2.9 $\mathrm{Ga}$. There are two main types of young granite: medium-grained biotite granite and porphyry granites and the main intrusive episode appears to have been 2.8 $\mathrm{Ga}$. The structures of this domain are the results of two major paleo-Proterozoic deformations: the first results from tangential tectonics [1] at the origin of structures oriented NS to NNE-SSW. The second corresponds to a transcurrent deformation [2]. It is underlined by the setting up, around $2.1 \mathrm{Ga}$, of large sets of granitoids.

The Kasila Group is an NW-SE trending strip of highly deformed and metamorphosed amphibolites to granulite-facies metasedimentary and meta-igneous rocks of Paleoproterozoic age [3]. In Vaama area we speak of orthogneiss 


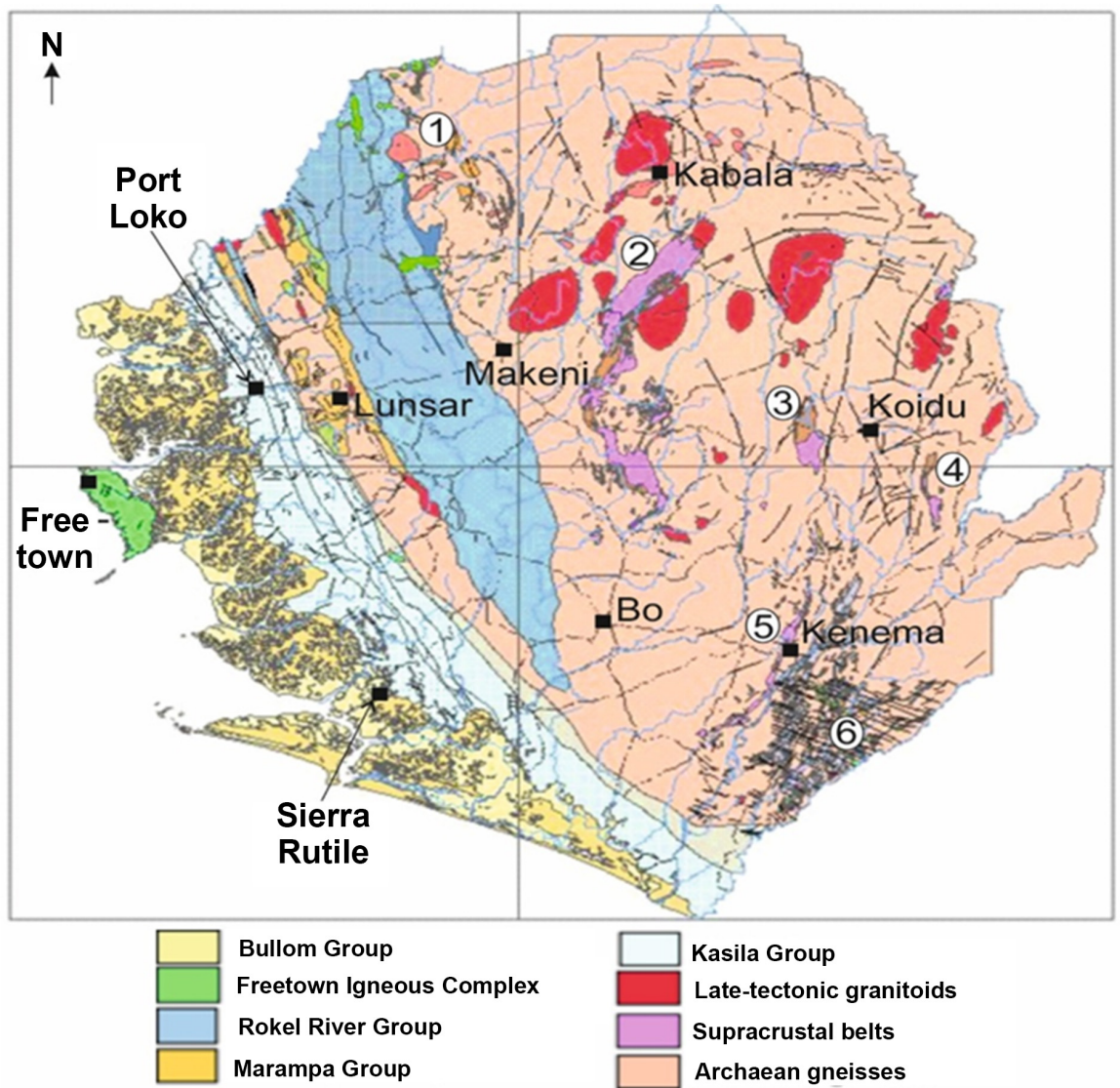

Figure 1. Simplified geological map of Sierra Leone, derived from the national map (CGS, 2004), ( ) National Minerals Agency. Major lithologies indicated in key. The width of the country is c. $250 \mathrm{~km}$, from the most easterly to most westerly point.

because it comes from the metamorphism of granite. It contains quartz, mica, plagioclase feldspars and sometimes alkaline feldspar, all large enough to be identified with the naked eye. The foliation, always present, is sometimes marked by the alternation of small light beds and darker levels (metamorphic bedding).

\subsection{Mechanical Properties of the Aggregates}

The two materials used in the study are basalt and gneiss. The objective is to evaluate the performance of the gneiss compared to that of the basalt.

The asphalt concrete is BBSG 0/14 with the following aggregate grades: 0/5, $5 / 10$ and 10/14. The characterization will focus on the following tests:

- particle size analysis(NF EN 933-1),

- the absolute density (NF P 18-554),

- the apparent density (NF P 98-250-1),

- MDE wear resistance (EN 1097-1),

- resistance to fragmentation due to shock (NF EN 1097-2),

- the flattening coefficient (NFEN 933-3),

- absorption, 
- cleanliness NF-P18591.

Figure 2 shows that the particle size analysis gives the same curves. The only difference to note is that basalt crushed sand has more fine particles (at sieve $0.075 \mathrm{~mm}$ the proportion passing is $14 \%$ while that of gneiss is $9.7 \%$ ).

The values specified in the technical specifications are given in Table 1.

Table 2 shows the summary of laboratory results of aggregates.

Basalt is heavier than gneiss (the unit weight of basalt is greater than that of gneiss). If we compare the ACV (Aggregate Compact Value) and LA (Los Angeles) values, we see that the basalt is more resistant to shock and abrasion.

Thus, it is easier to crush the gneiss, which justifies why the flakiness index $5 / 10$ and 10/14 classes of the latter are lower than those of the basalt.

Although gneiss absorbs more than basalt, both types of aggregates have low absorption percentages compared to the limit specified.

The sulphate and sulphide contents $(1.22$ and $1.18<12 \%)$ can't affect the chemical affinity of pebbles with cement and bitumen.

\section{Asphalt Hot Mix Design with Gneiss and Basalt Aggregates}

The volumetric mix design is based on empirical performance-related aggregate and mixture properties. Empirical properties are used to ensure adequate performance for lower volume pavements and to provide the formula [4].

The Marshall mix design method consists of 6 basic steps:

1) Aggregate selection,

2) Asphalt binder selection,

3) Sample preparation (including compaction),

4) Stability determination using the Hveem Stabilometer,

5) Density and voids calculations,

6) Optimum asphalt binder content selection.

Compaction with the Marshall Hammer

Each sample is then heated to the anticipated compaction temperature and compacted with a Marshall hammer, a device that applies pressure to a sample through a tamper foot.

\subsection{Composition of the Mix}

From Figure 2 we perform a theoretical mix for each type of aggregate. The theoretical mix is in the envelop specified.

Table 3 shows the percentage for each class of aggregate.

The theoretical and practical mixtures of the two different types of aggregates fit well into the granular envelope.

The theoretical curve of the basalt granulate is in a median position within the envelope whereas that of the gneiss appears slightly coarse. This is logical because $0 / 5$ crushed sand basalt has more fine elements (sieve $0.075 \mathrm{~mm}$ has $14 \%$ passing) (Figure 3, Figure 4). 

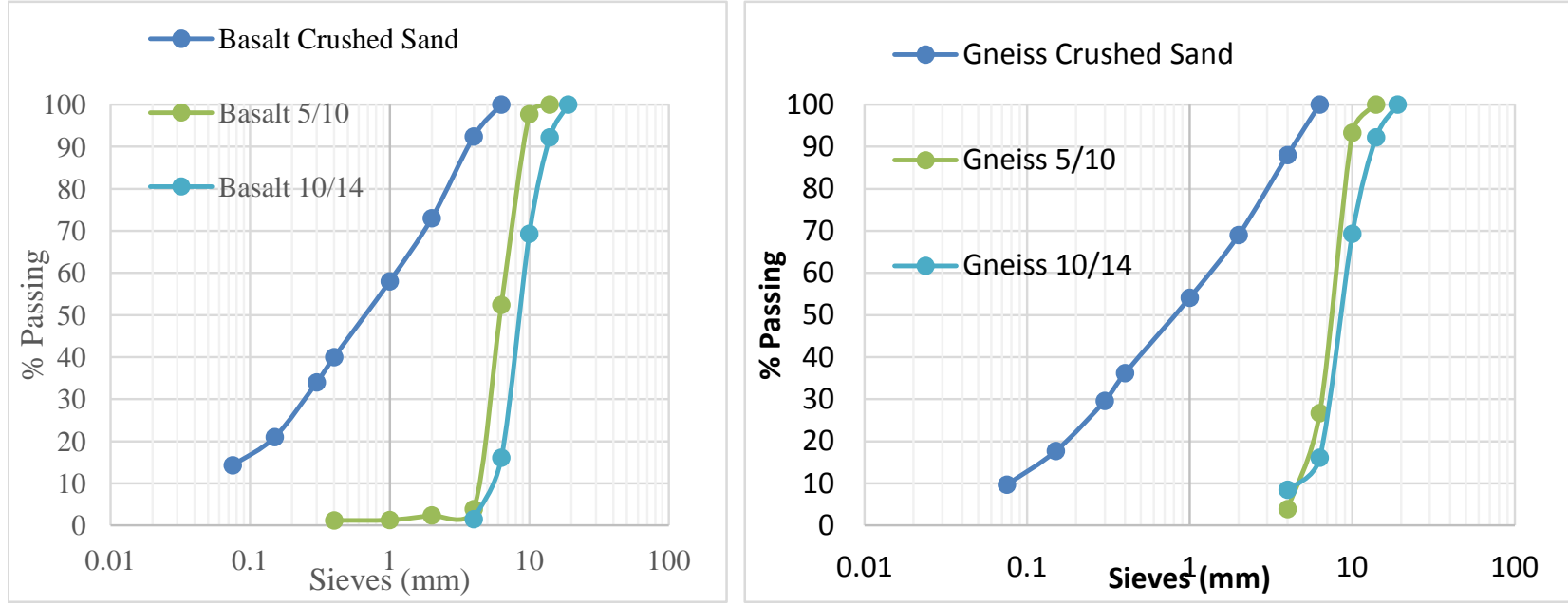

Figure 2. Sieve analysis of gneiss and basalt aggregate.

Table 1. Technical specifications of the aggregates.

\begin{tabular}{ccccccc}
\hline Micro Deval & Los Angeles & Flakiness & Absorption & cleanliness & $\begin{array}{c}\text { Sodium Sulfate } \\
\text { Soundness }\end{array}$ & $\begin{array}{c}\text { Sand } \\
\text { Equivalent }\end{array}$ \\
\hline$<25$ & $<35$ & $<20$ & $<2.5$ & $<5$ & $<12$ & $>40$ \\
\hline
\end{tabular}

Table 2. Laboratory test results of aggregates.

\begin{tabular}{|c|c|c|c|c|c|c|c|c|c|}
\hline Materials & $\begin{array}{l}\text { Aggregates } \\
\text { class }\end{array}$ & $\begin{array}{l}\text { Unit Weight } \\
\qquad\left(\mathrm{g} / \mathrm{cm}^{3}\right)\end{array}$ & $\begin{array}{c}\text { Maximun } \\
\text { Specific gravity } \\
\left(\mathrm{g} / \mathrm{cm}^{3}\right)\end{array}$ & $\begin{array}{l}\text { Micro } \\
\text { Deval }\end{array}$ & Los Angeles & Flakiness & Absorption & Cleanliness & $\begin{array}{c}\text { Sodium } \\
\text { sulfate } \\
\text { Soundness }\end{array}$ \\
\hline \multirow{3}{*}{ Basalt } & $0 / 5$ & 1.78 & 2.93 & & & & 0.1 & & \multirow{3}{*}{1.22} \\
\hline & $5 / 10$ & 1.48 & 2.97 & 16 & & 18 & 0.08 & 2 & \\
\hline & $10 / 14$ & 1.52 & 2.98 & 14 & 18 & 8 & 0.08 & 0.9 & \\
\hline \multirow{3}{*}{ Gneiss } & $0 / 5$ & & 2.62 & & & & 0.19 & & \multirow{3}{*}{1.18} \\
\hline & $5 / 10$ & & 2.64 & 23 & & 10 & 0.504 & 2.3 & \\
\hline & $10 / 14$ & & 2.7 & 20 & 29 & 6 & 0.324 & 1 & \\
\hline
\end{tabular}

Table 3. Theoretical composition for each type of aggregate.

\begin{tabular}{ccc}
\hline Aggregate class & Basalt & Gneiss \\
\hline $0 / 5$ Crushedsand & $50 \%$ & $52 \%$ \\
$5 / 10$ & $25 \%$ & $14 \%$ \\
$10 / 14$ & $25 \%$ & $34 \%$ \\
\hline
\end{tabular}

\subsection{Bitumen Characteristics}

50/70 bitumen is used. Bitumen is a very useful and valuable material for the construction of flexible pavements around the world.

The tests carried out to characterize the binder are: needle penetration (NF EN 1426), the softening point test (NFEN 1427), the aging test (NF EN 12607-1), the bright spot and the relative density [4] (Table 4). 

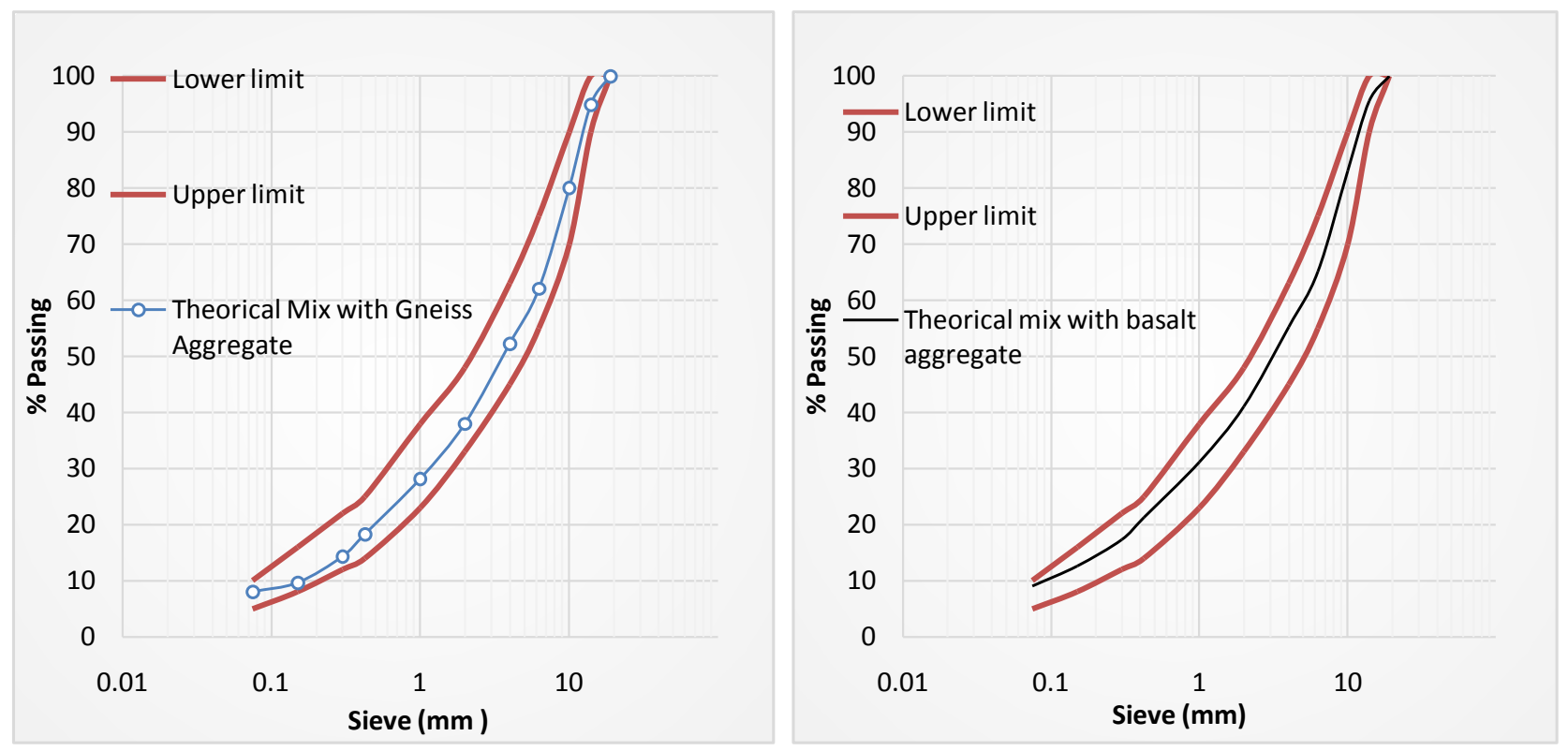

Figure 3. Theoretical mix for the basalt and gneiss aggregate.
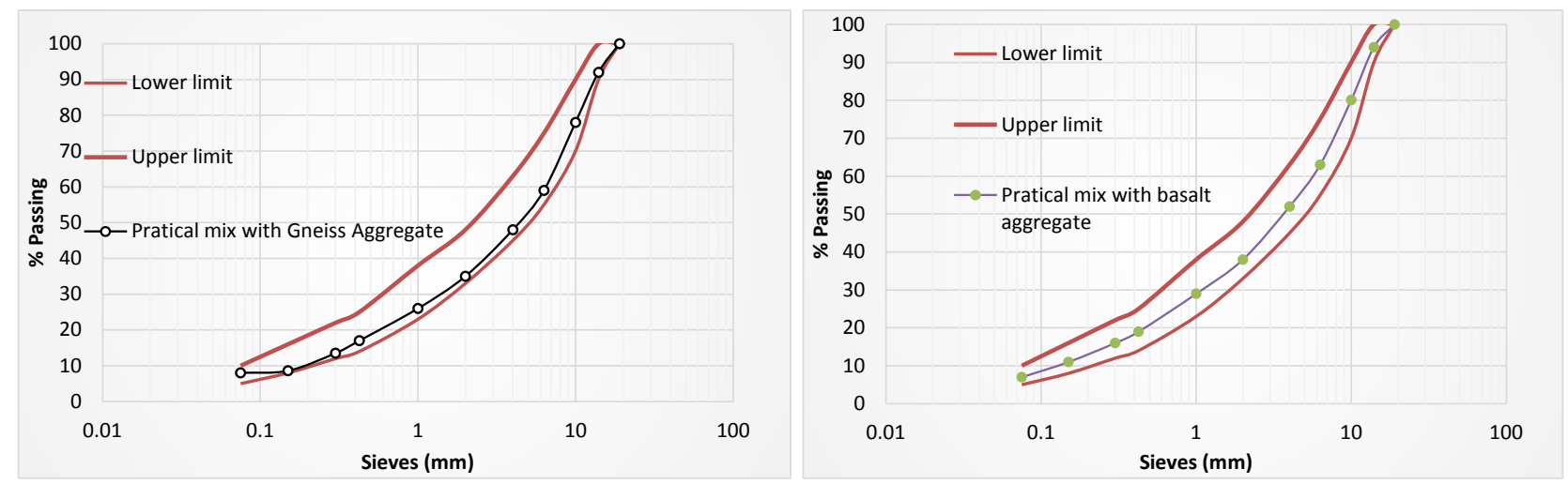

Figure 4. Grading after extraction of bitumen for the basalt and gneiss aggregate.

Table 4. Laboratory test for 50/70 bitumen.

\begin{tabular}{|c|c|c|c|c|}
\hline Standards & & Trials & reading & Specifications \\
\hline NF EN 1426 & & Penetration test & 60 & $50-70$ \\
\hline NF EN 1427 & & Soft point & $49.6^{\circ} \mathrm{C}$ & $46-54$ \\
\hline \multirow[b]{2}{*}{ NF EN 12607-1 } & \multirow[b]{2}{*}{ RTFOT } & Weight variation $\%$ & 0.4 & \pm 0.5 \\
\hline & & $\begin{array}{l}\text { Balance penetration } \\
\qquad(1 / 10 \mathrm{~mm})\end{array}$ & 59 & $\geq 50$ \\
\hline
\end{tabular}

\subsection{Asphalt Bitumen Content}

\subsubsection{Test Procedure}

Binder content is one of the most important characteristics of asphalt concrete. Use of the proper amount of binder is essential to good performance in asphalt concrete mixtures. Typical asphalt binder contents range from $3.0 \%$ or less (for 
lean base course mixtures) to over $6.0 \%$ (for surface course mixtures and rich bottom layers), which are designed for exceptional durability and fatigue resistance [4].

After mixing bitumen, crushed sand, 5/10 aggregate and 10/14 aggregate for each type, we compact the specimen at $140^{\circ} \mathrm{C}$ (Figure 5).

\subsubsection{Marshall Test: Summary of Laboratory Results}

After hydrostatic weighing and Marshall stability reading, the results are given in Table 5.

The test sets are used to determine the physical and mechanical properties of bituminous mixtures, especially for the water sensitivity of bituminous specimens. One set is for preparing $80 \mathrm{~mm}$ specimens, the second set is for preparing $120 \mathrm{~mm}$ specimens according to the maximum aggregate upper sieve size. All parts are made from steel protected against corrosion [5].

Seven specimens were compacted.

- One is used to determine the bulk specific gravity;

- three specimens are immersed in water at $18^{\circ} \mathrm{C}$ for 7 days;

- three specimens are stored in air at $18^{\circ} \mathrm{C}$ for 7 days.

The results of the Duriez test are presented in Table 6.

The ratio $\mathrm{r} / \mathrm{R}$ is greater than 0.75 for the four types of mix, so we conclude that we have a good water resistance with the samples.

\subsubsection{Calculation of the Stiffness Modulus by Diametric Compression Test}

Theoretical study is based on the theory of elasticity for the computation of stress and deformation described in detail by Frocht [6]. The indirect tensile test can be modeled as follows: (Figure 6)

We can establish the following geometric relations at any point in the sample:

$$
\begin{aligned}
& r_{1}^{2}=x^{2}+(R-y)^{2} \\
& r_{2}^{2}=x^{2}+(R+y)^{2}
\end{aligned}
$$

Assuming that the load $P$ is applied in the same diametric plane, that the material is homogeneous isotropic and that the response is elastic-linear, the stress

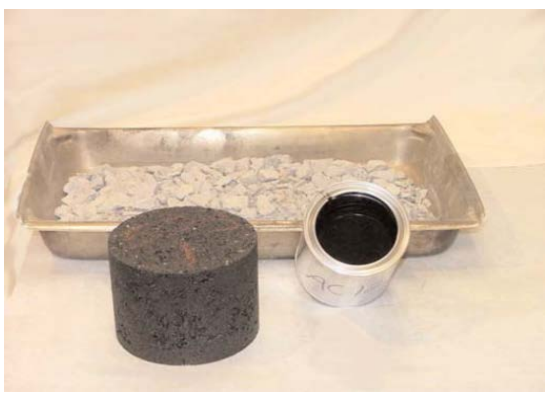

Figure 5. A compacted HMA laboratory specimen and the aggregate and asphalt used to prepare it. 
Table 5. Marshall and Compaction test results.

\begin{tabular}{|c|c|c|c|c|c|c|c|c|}
\hline$\%$ Bitumen/Criteria & & 4 & 4.5 & 5 & 5.5 & 6 & 6.5 & $\begin{array}{c}\text { Technical } \\
\text { Specifications }\end{array}$ \\
\hline \multirow{5}{*}{ Stability $(\mathrm{kg})$} & Gneiss & 1490 & 1525 & 1550 & 1540 & 1400 & - & \multirow{4}{*}{$>1000 \mathrm{~kg}$} \\
\hline & Gneiss $+2 \%$ filler & & 1625 & 1712 & 1821 & 1762 & - & \\
\hline & Gneiss $+2 \%$ filler $+2 \%$ cement & - & 1242 & 1418 & 962 & 955 & - & \\
\hline & Basalt & & 1520 & 1700 & 2100 & 2000 & 1715 & \\
\hline & Gneiss & 2 & 2.4 & 2.7 & 3 & 3.45 & - & \multirow{4}{*}{$2-4$} \\
\hline \multirow{3}{*}{ Flow $(\mathrm{mm})$} & Gneiss $+2 \%$ filler & - & 2.06 & 2.5 & 2.6 & 2.7 & - & \\
\hline & Gneiss $+2 \%$ filler $+2 \%$ cement & - & 1.97 & 2.25 & 2.5 & 2.85 & - & \\
\hline & Basalt & - & 2 & 2.4 & 2.7 & 3 & 3.45 & \\
\hline \multirow{4}{*}{$\begin{array}{l}\text { Bulk specific gravity } \\
\qquad\left(\mathrm{g} / \mathrm{cm}^{3}\right)\end{array}$} & Gneiss & 2.36 & 2.375 & 2.379 & 2.381 & 2.332 & & \\
\hline & Gneiss $+2 \%$ filler & & 2.302 & 2.335 & 2.345 & 2.281 & & \\
\hline & Gneiss $+2 \%$ filler $+2 \%$ cement & & 2.29 & 2.344 & 2.345 & 2.3 & & \\
\hline & Basalt & & 2.574 & 2.604 & 2.601 & 2.545 & 2.603 & \\
\hline \multirow{4}{*}{$\begin{array}{l}\text { Maximun specific } \\
\text { gravity }\left(\mathrm{g} / \mathrm{cm}^{3}\right)\end{array}$} & Gneiss & 2.501 & 2.486 & 2.482 & 2.476 & 2.469 & & \\
\hline & Gneiss $+2 \%$ filler & & 2.48 & 2.461 & 2.45 & 2.391 & & \\
\hline & Gneiss $+2 \%$ filler $+2 \%$ cement & & 2.48 & 2.45 & 2.45 & 2.451 & & \\
\hline & Basalt & & 2.721 & 2.701 & 2.674 & 2.661 & 2.643 & \\
\hline \multirow{4}{*}{ Compaction } & Gneiss & $94 \%$ & $96 \%$ & $96 \%$ & $96 \%$ & $94 \%$ & & \multirow{4}{*}{$>93 \%$} \\
\hline & Gneiss $+2 \%$ filler & & $93 \%$ & $95 \%$ & $96 \%$ & $95 \%$ & & \\
\hline & Gneiss $+2 \%$ filler $+2 \%$ cement & & $92 \%$ & $96 \%$ & $96 \%$ & $94 \%$ & & \\
\hline & Basalt & & $95 \%$ & $96 \%$ & $97 \%$ & $96 \%$ & $98 \%$ & \\
\hline \multirow{5}{*}{ Air Void } & Gneiss & $5.21 \%$ & $5.1 \%$ & $4.1 \%$ & $3.4 \%$ & $3.0 \%$ & & \multirow{5}{*}{$3-8$} \\
\hline & Gneiss $+2 \%$ filler & & $7.7 \%$ & $7.1 \%$ & $6.1 \%$ & $5.2 \%$ & & \\
\hline & & & & & & & & \\
\hline & Gneiss $+2 \%$ filler $+2 \%$ cement & & $7.7 \%$ & $7.0 \%$ & $6.5 \%$ & $5.3 \%$ & & \\
\hline & Basalt & & $8.0 \%$ & $6.0 \%$ & $5.0 \%$ & $3.0 \%$ & $2.6 \%$ & \\
\hline \multirow{4}{*}{ VMA (\%) } & Gneiss & 15 & 15.5 & 16.2 & 16.8 & 17 & & \multirow{4}{*}{$>15$} \\
\hline & Gneiss $+2 \%$ filler & & 17.84 & 18.35 & 18.46 & 18.55 & & \\
\hline & Gneiss $+2 \%$ filler $+2 \%$ ciment & & 17.83 & 18.28 & 18.8 & 18.82 & & \\
\hline & Basalte & & 17.8 & 17.9 & 18.4 & 18.6 & 19.1 & \\
\hline \multirow{5}{*}{ VFA (\%) } & Gneiss & 62 & 67 & 77 & 79 & 80 & & \multirow{5}{*}{$65-75$} \\
\hline & Gneiss $+2 \%$ filler & & 56.68 & 61.19 & 67.18 & 72.14 & & \\
\hline & & & & & & & & \\
\hline & Gneiss $+2 \%$ filler $+2 \%$ ciment & & 56.74 & 61.47 & 65.68 & 71.93 & & \\
\hline & Basalte & & 62 & 67 & 77 & 79 & 80 & \\
\hline
\end{tabular}


Table 6. Results of the Duriez test on the four types of formulations

\begin{tabular}{ccccc}
\hline Formulations & Materials & $\begin{array}{c}\text { Compressive Strength@7 days } \\
\text { in water r (MPa) }\end{array}$ & $\begin{array}{c}\text { Compressive Strength@7 } \\
\text { days in air R (MPa) }\end{array}$ & $\begin{array}{c}\text { Rapport r/R } \\
\text { F1 }\end{array}$ Gneiss \\
F2 & Gneiss+ 2\% filler & 4.9 & 5.81 & 0.84 \\
F3 & Gneiss + 2\% filler + 2\% cement & 5.00 & 5.90 & 0.85 \\
F4 & Basalt & 5.80 & 7.00 & 0.83 \\
\hline
\end{tabular}

$\mathrm{Ox}$

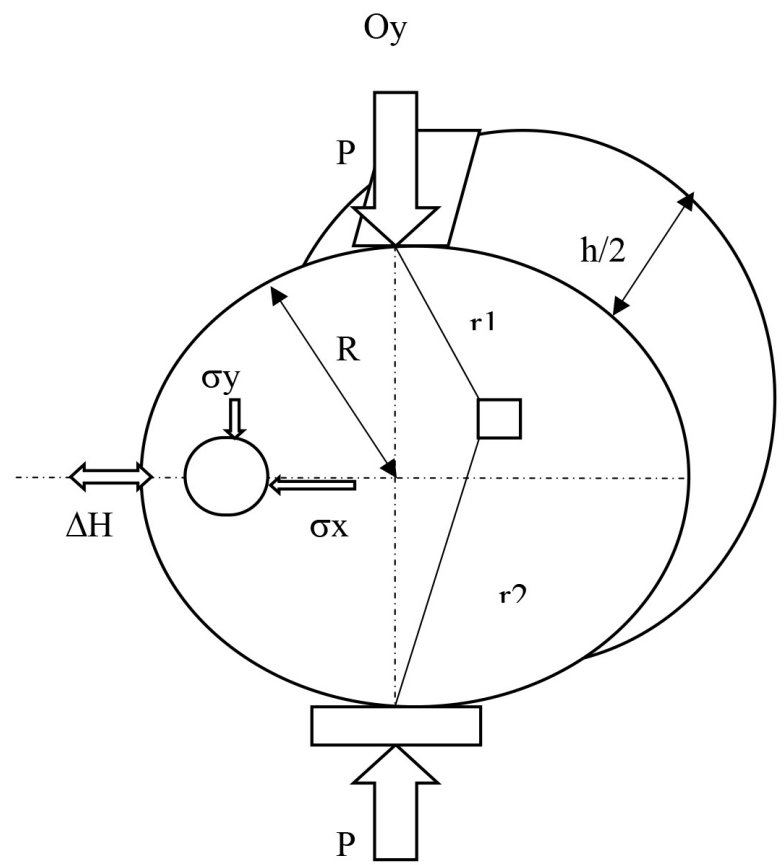

Figure 6. Model of the indirect tensile test (diametric compression test). $P$ : load; $d$ : diameter of specimen; $h$ : height of specimen $(\mathrm{Oz}) ; R$ : radius of specimen; $H$ : displacement according $O x$.

values are expressed at any point of the stressing plane according to the developments of deformation [7], which repeats the work of Kennedy (1945):

$$
\begin{gathered}
\sigma x=\frac{-2 P}{\pi h}\left(\left(\frac{(R-y) x 2}{r_{1} 4}+\frac{(R+y) x 2}{r_{2} 4}\right)-\frac{1}{d}\right) \\
\sigma y=\frac{-2 P}{\pi h}\left(\left(\frac{(R-y) 3}{r_{1} 4}+\frac{(R+y) 3}{r_{2} 4}\right)-\frac{1}{d}\right) \\
\tau x y=\frac{-2 P}{\pi h}\left(\frac{(R-y) 2 x}{r_{1} 4}+\frac{(R+y) 2 x}{r_{2} 4}\right)
\end{gathered}
$$

The indirect tensile test serves to measure the deformations perpendicular to the application of the force which is made according to $\sigma y$. We can observe that at every point $\sigma x$ is positive and $\sigma y$ is negative (compression). The constraints on the $\sigma x$ axis are minimal (zero) at the edge of the sample $(x= \pm d / 2)$. The 
maximum stresses are in the center of the specimen, when $x=y=0$. The state of constraint is then the following:

$$
\begin{array}{r}
\sigma x=\frac{-2 P}{\pi h d} \\
\sigma y=\frac{-6 P}{\pi h d}
\end{array}
$$

Similarly, the constraints in the plane $(\sigma y)$ can be calculated according to an identical procedure. The stress $\sigma x$ is then a uniform traction equal to $2 P / \pi h d$.

Considering that the stresses and deformations satisfy the law of elasticity, we can calculate the deformation $\sigma x$ at a point of the $\sigma x$ axis by Hooke's law (bi axial case).

$$
\varepsilon x=\frac{1}{E x}(\sigma x-(v \cdot \sigma y))
$$

By integrating Equations (3) and (4) in the formula and $\varepsilon x$ (Equation (5)), the displacement $\Delta H$ can be expressed as:

$$
\Delta H=\int_{-d / 2}^{d / 2} \varepsilon x \mathrm{~d} x=\left(\frac{P}{h \cdot E x}\right)\left(\frac{4}{\pi}+v-1\right)
$$

By simplification of Equation (6) the value of the module is:

$$
E x=\frac{P(v+0.27)}{\Delta H \cdot h}
$$

The modulus of elasticity is calculated using an approximate value of the fish coefficient (Di Benedetto and Corte 2004).

In our study, we consider that the fish coefficient is 0.35 .

a) Mix design with gneiss granulate (F1)

The observation of Figures 7-10 shows that:

- the flow is greater than $2 \mathrm{~mm}$ from $4.5 \%$ of bitumen content,

- a maximum compaction at $5 \%$ of bitumen content and a VFA value $>65$,

- the percentage of voids is greater than 4 , which makes it very close to the median value of $5.5 \%$,

- the module reaches a maximum value at $5 \%$ of bitumen content.

From these observations, the value $4.75 \% \pm 0.25 \%$ is selected as the optimum bitumen content.

b) Mix Design gneiss $+2 \%$ filler (F2)

The analysis of Figures 11-14 shows optimal values, parameters commented above, between $5.0 \%$ and $5.5 \%$ of bitumen content. At 5.5\% bitumen the void percentage and the modules experience a nearly identical linear regression.

The optimum bitumen content retained is $5.25 \% \pm 0.25 \%$.

c) Mix Design gneiss $+2 \%$ filler $+2 \%$ cement (F3)

Figures 15-18 show that between 4.8 and 5.4\% in bitumen content, we have the values of creep, stability, compactness, VCB and percentage of voids that respond well to technical specifications of the project (Figures 19-22). 


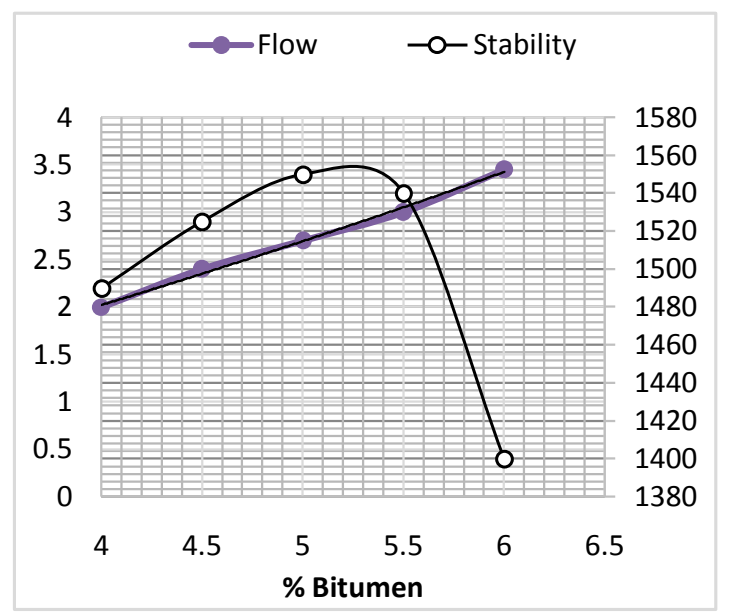

Figure 7. Variation of stability and flow in relation to bitumen content (Gneiss granulate).

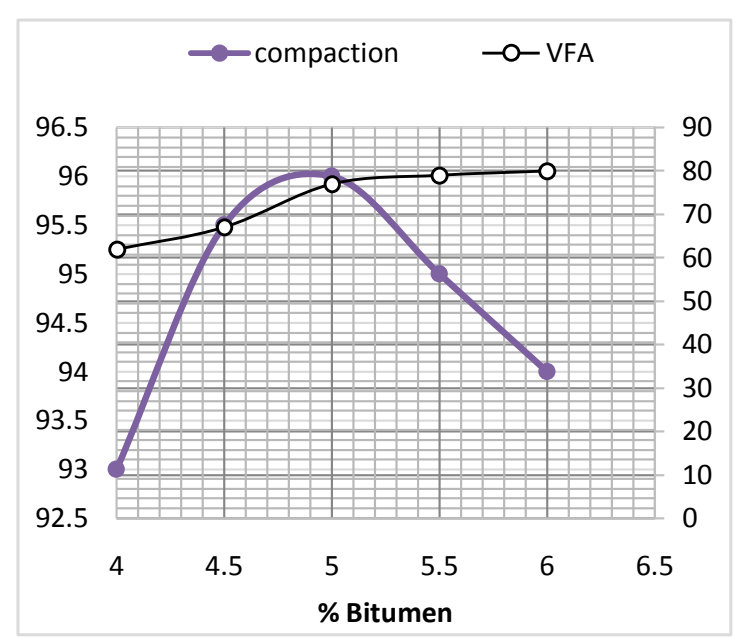

Figure 8. Variation of compaction and VFAin relation to bitumen content (Gneiss granulate).

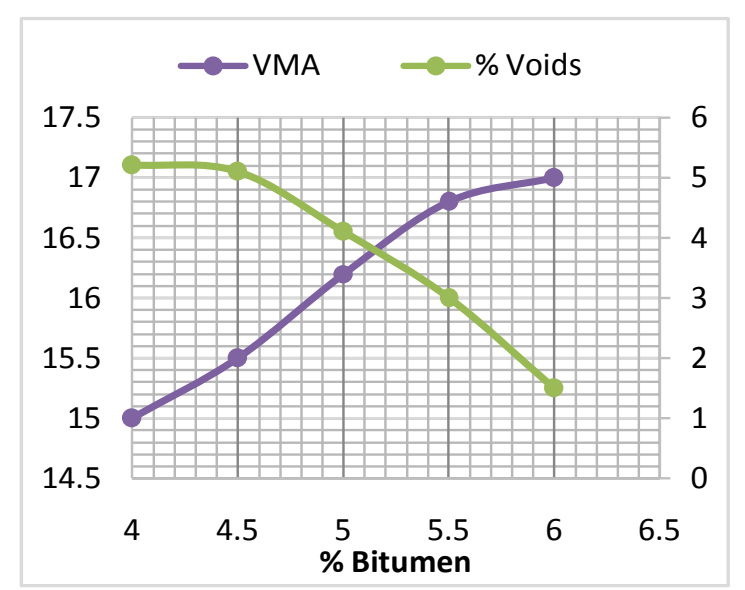

Figure 9. Variation of VMA and voids in relation to bitumen content (Gneiss granulate). 


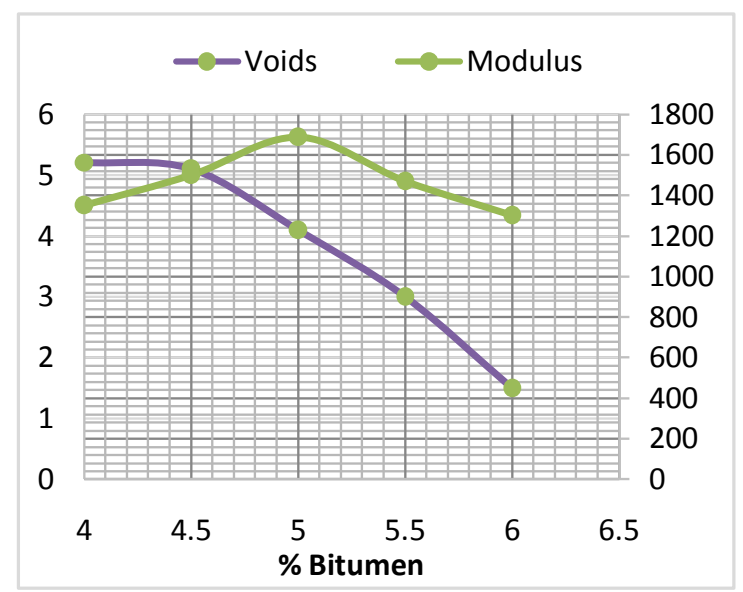

Figure 10. Variation of voids and modulus in relation to the bitumen content (Gneiss granulate).

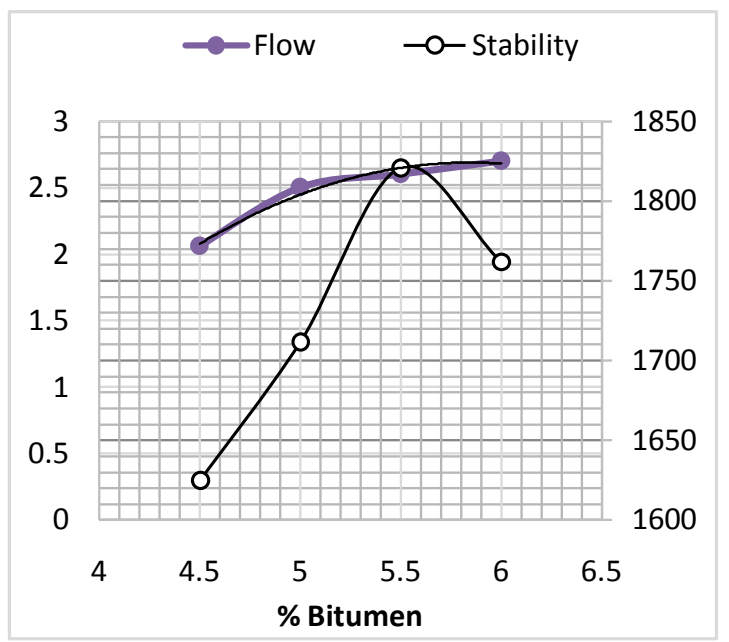

Figure 11. Variation of stability and flow in relation to bitumen content (Gneiss $+2 \%$ filler).

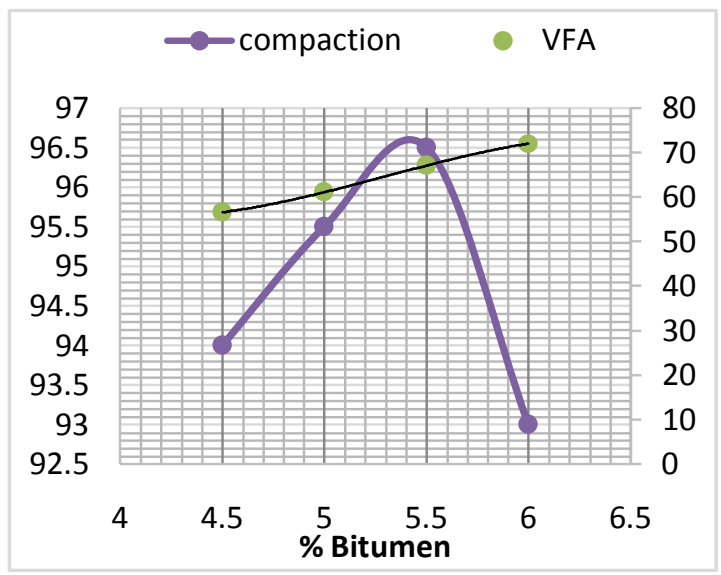

Figure 12. Variation of compaction and VFA in relation to bitumen content (Gneiss $+2 \%$ filler). 


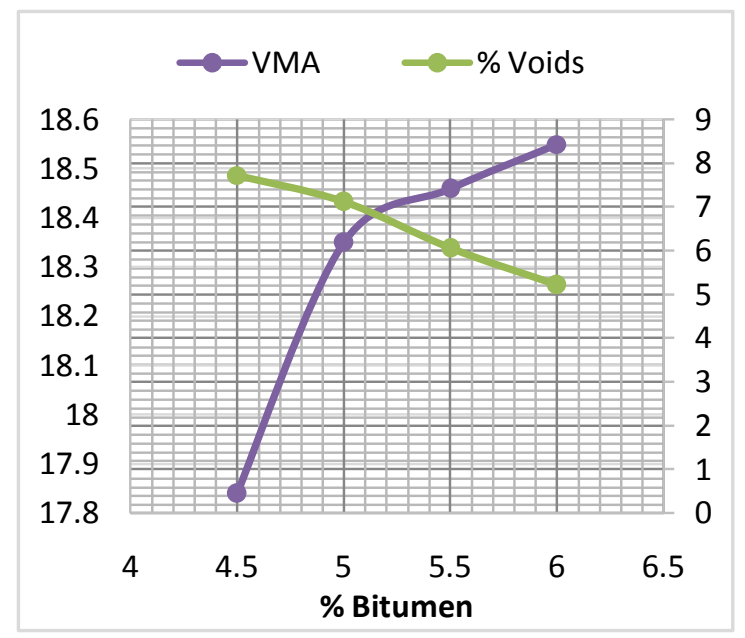

Figure 13. Variation of VMA and voids in relation to bitumen content (Gneiss $+2 \%$ filler).

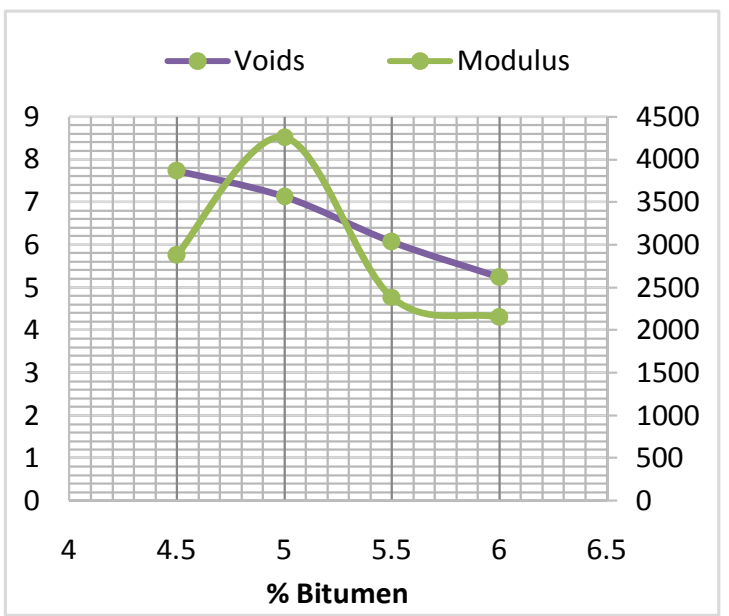

Figure 14. Variation of voids and modulus in relation to bitumen content (Gneiss $+2 \%$ filler).

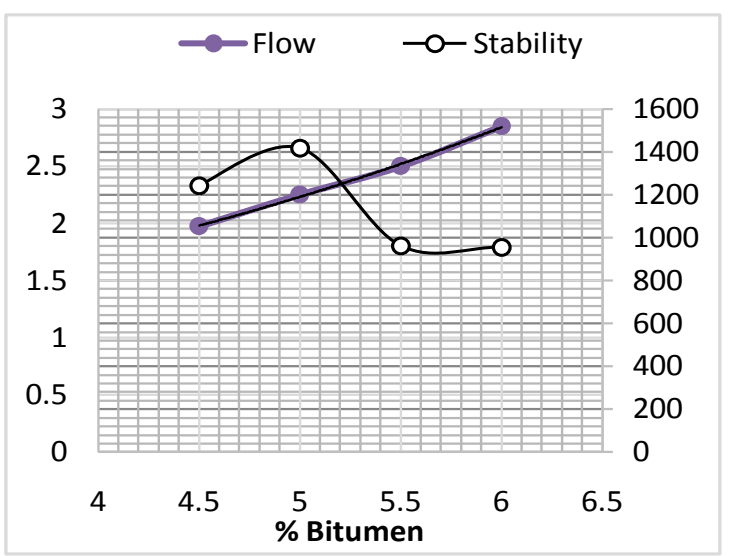

Figure 15. Variation of stability and creep in relation to bitumen content (Gneiss + filler + cement). 


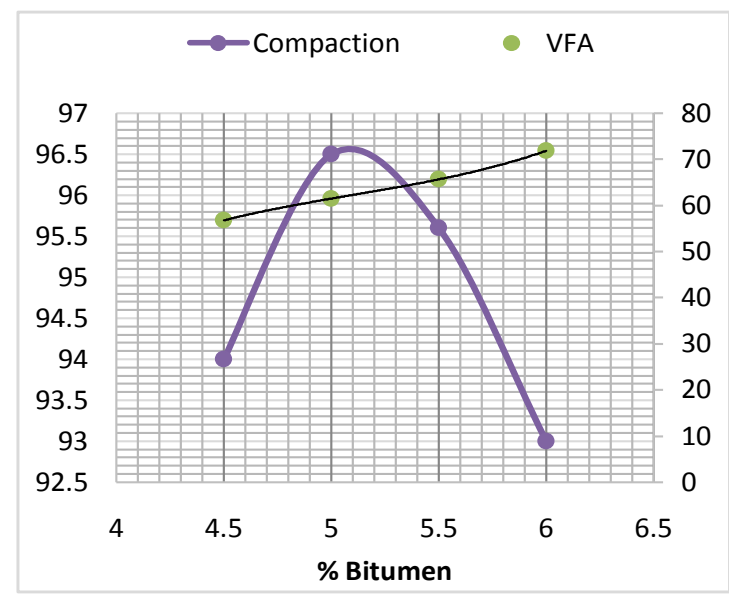

Figure 16. Variation of compactness and VFA in relation to bitument content (Gneiss + filler + cement).

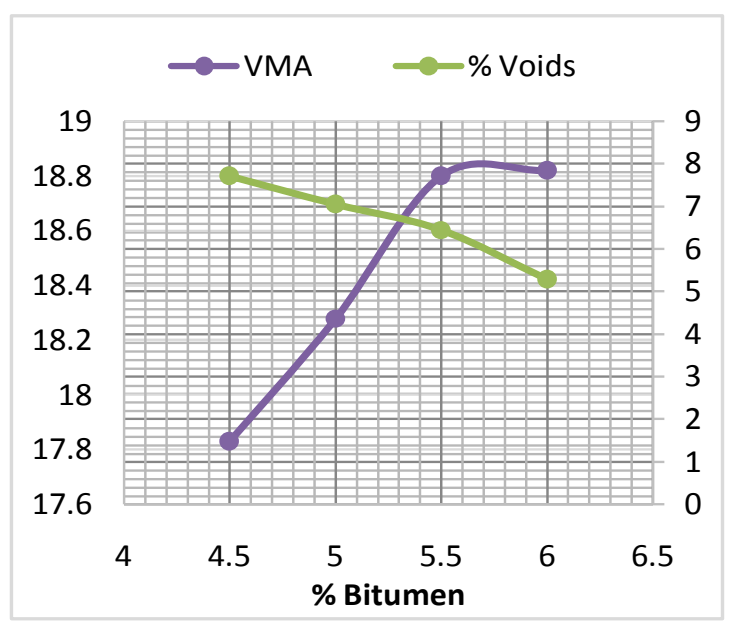

Figure 17. Variation of VAM and voids in relation to bitumen content (Gneiss + filler + cement).

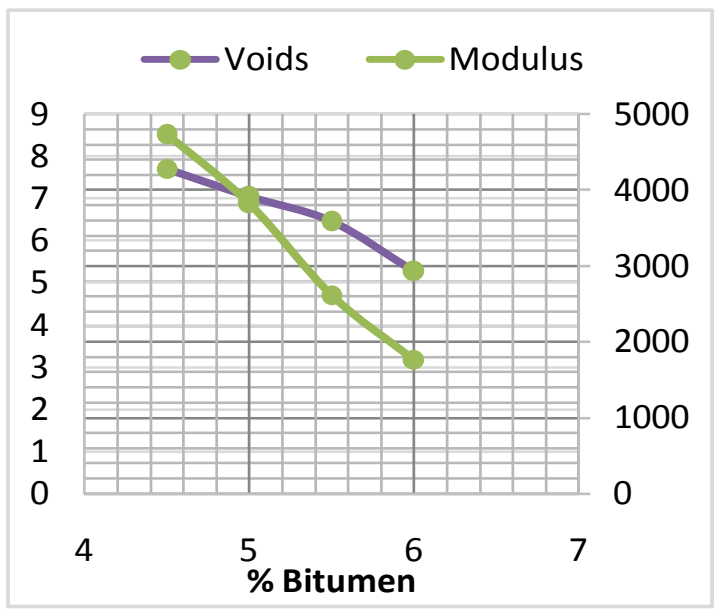

Figure 18. Variation of voids and modules in relation to Bitumen content (Gneiss + filler+ cement). 


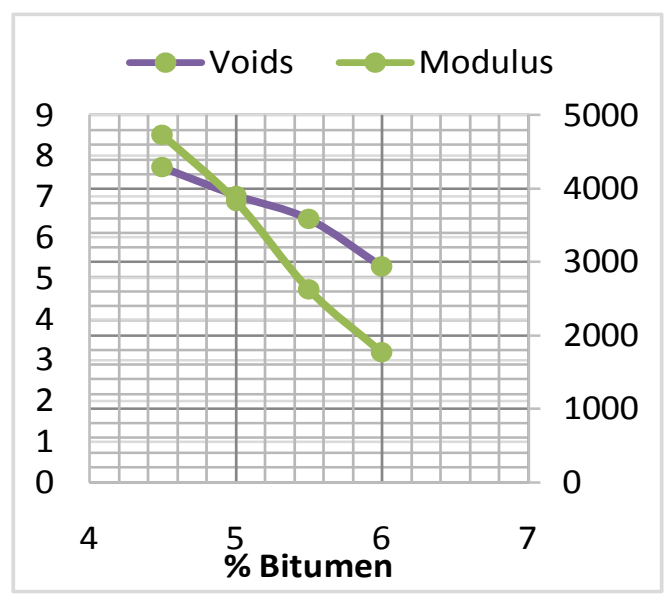

Figure 19. Variation of stability and creep in relation to bitumen content (Basalt granulate).

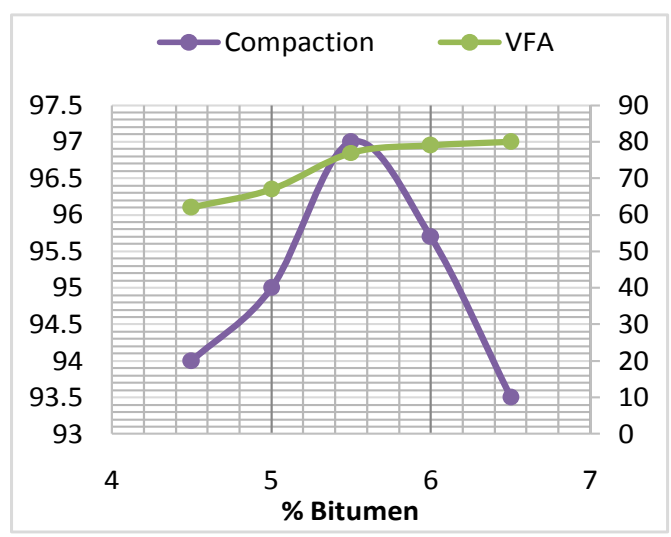

Figure 20. Variation of compactness and VCB in relation to bitument content (Basalt granulate).

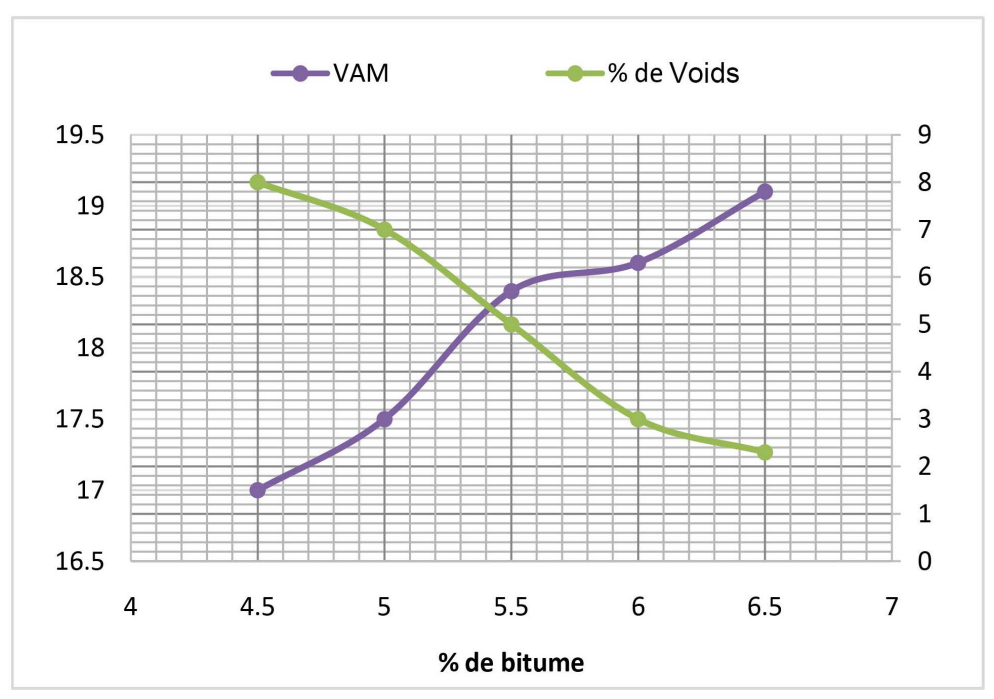

Figure 21. Variation of VAM and voids in relation to bitumen content (Basalt granulate). 


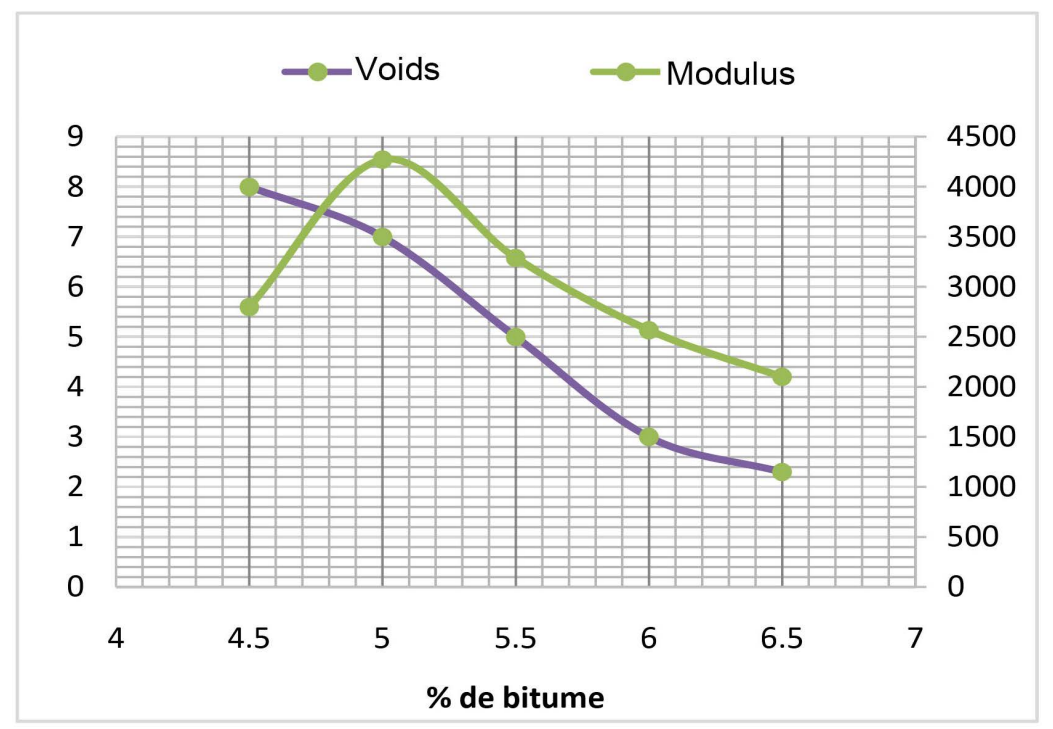

Figure 22. Variation of voids and modules in relation to Bitumen content (Basalt granulate).

The optimum bitumen content value chosen is $5.1 \% \pm 0.3 \%$.

d) Mix design with basalt granulate (F4)

The mix design with basalt granulate shows these best performances in the range $5 \%-6 \%$ binder content.

The optimum value of the binder content chosen is $5.5 \% \pm 0.5 \%$.

The results of these formulas are summarized in Table 7.

The formula F3 also meets the project specifications, but has marginal values: the stability is $1200 \mathrm{~kg}$, the percentage of voids $7 \%$, is very close to the limit 8 . The module is $4000 \mathrm{MPa}$, the layer is stiffened while the compaction is $93 \%$. These facts will cause an early loss of compactness under the effect of traffic.

The mix design F2 and F4 have more similarities in their performance.

\section{Concrete Mix Design}

We used the DREUX-GORISSE method. It has to determine, according to the criteria of workability and resistance defined by the specifications, the nature and the quantities of materials necessary for the batch of a cubic meter of concrete (water $\mathrm{W}$, cement $\mathrm{C}$, sand $\mathrm{S}$, chippings $\mathrm{g}$ and gravel $\mathrm{G}$ in $\mathrm{kg} / \mathrm{m}^{3}$ ).

The main parameters to be defined are: the workability and strength of the concrete, the nature of the cement and the type of aggregates.

Workability is characterized, amongst other things, by the value of the slump test. It is chosen according to the type of work to be carried out, the embodiment and the vibration methods available on site [8].

Two types of mix design are studied with two types of aggregates: basalt and gneiss (Figure 23).

Table 8 shows the laboratory test results of sand and aggregate.

a) Concrete for Box culverts, pipe culverts and line drains 
Table 7. Characteristic values for optimum bitumen content by type of mix design The mix design F1 and F2 meet the technical specifications of the project.

\begin{tabular}{|c|c|c|c|c|c|c|c|c|}
\hline Formulations & Material & $\%$ bitumen & Stability (kg) & Fluage $(\mathrm{mm})$ & VCB \% & Voids \% & Compaction \% & Module MPA \\
\hline F1 & Gneiss & 4.75 & 1500 & 2.5 & 73 & 4.4 & 95.6 & 1600 \\
\hline F2 & $\begin{array}{c}\text { Gneiss }+2 \% \\
\text { filler }\end{array}$ & 5.25 & 1775 & 2.60 & 66.00 & 6.50 & 93.50 & 3750 \\
\hline F3 & $\begin{array}{c}\text { Gneiss }+2 \% \\
\text { filler }+2 \% \\
\text { ciment }\end{array}$ & 5.10 & 1200 & 2.25 & 65.00 & 7.00 & 93.00 & 4000 \\
\hline F4 & Basalte & 5.5 & 2100 & 2.7 & 70 & 5 & 95 & 3500 \\
\hline SPECIFICATIONS & & $>4 \%$ & $>1000 \mathrm{~kg}$ & $2-4$ & $65-75$ & $3-8$ & $>93 \%$ & $>1300 \mathrm{MPa}$ \\
\hline
\end{tabular}

Table 8. Laboratory test results of the sand, gneiss and basalt aggregate.

\begin{tabular}{ccccccc}
\hline Materials & Classes & Specificgravity $\left(\mathrm{g} / \mathrm{cm}^{3}\right)$ & Unit weight $\left(\mathrm{g} / \mathrm{cm}^{3}\right)$ & Flakiness (\%) & Fine modulus & Sand equivalent (\%) \\
\hline Gneiss & $5 / 14$ & 2.801 & 1.510 & 9.50 & - & - \\
& $14 / 20$ & 2.903 & 1.520 & 4.40 & - & - \\
Basalt & $5 / 14$ & 2.883 & 1.547 & 5.50 & - & - \\
& $14 / 20$ & 2.949 & 1.588 & 5.00 & - & 81.00 \\
\multirow{2}{*}{ River sand } & River sand & 3.028 & 1.670 & - & 3.05 & - \\
\hline
\end{tabular}
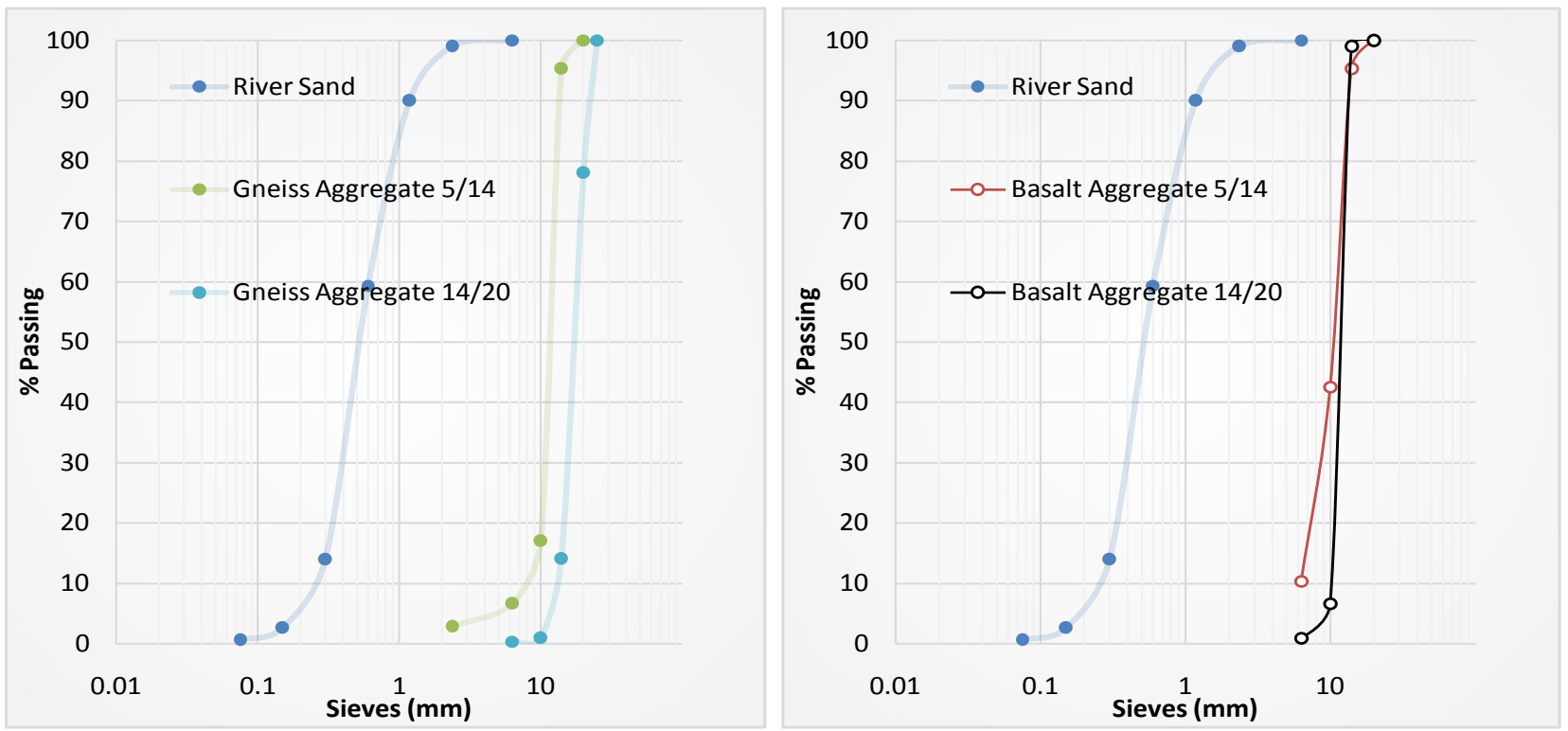

Figure 23. Aggregate grading for concrete.

The specifications are: $50 \mathrm{~mm}$ plastic concrete $<\mathrm{A}<90 \mathrm{~mm}$ and $\mathrm{Rc}_{28}=30$ $\mathrm{MPa}$.

The nominal strength of the target concrete will be $30 \times 1.15=34.5 \mathrm{MPa}$ with a slump of $70 \mathrm{~mm}$. For $1 \mathrm{~m}^{3}$ of concrete we made a composition summarized in Table 9.

The mixing test is carried out under normal three-layer vibration conditions. Nine samples are demolded after 24 hours and immersed; three will be crushed at seven days $\left(\mathrm{Rc}_{7}\right)$ and six at 28 days $\left(\mathrm{Rc}_{28}\right)$. 
Table 9. Composition for $1 \mathrm{~m}^{3}$ of concrete of the two types of gravel.

\begin{tabular}{cccccc}
\hline Materials & Cement (kg) & Water (liters) & Sand (kg) & Aggregate 5/14 (kg) & $\begin{array}{c}\text { Aggregate } \\
14 / 20(\mathrm{~kg})\end{array}$ \\
\hline Gneiss & 350 & 177 & 896 & 442 & 759 \\
Basalt & 350 & 178 & 744 & 440.00 & 859 \\
\hline
\end{tabular}

The results obtained are recorded in Table 10.

We note that at 28 days both mixes have results above $34.5 \mathrm{MPa}$.

So, we can use the gneiss granules in place of basalt for hydraulic concrete while respecting the requirements of the specifications.

The mix with basalt aggregates has a slight advantage in terms of current performance or at seven days it reached $100 \%$ of the target strength.

a) Concrete for the composite bridges

The specifications are: $70 \mathrm{~mm}$ plastic concrete $<\mathrm{A}<150 \mathrm{~mm}$ and $\mathrm{Rc}_{28}=35$ $\mathrm{MPa}$.

The nominal strength of the target concrete will be $35 \times 1.15=40.25 \mathrm{MPa}$ with a slump of $70 \mathrm{~mm}$. In addition it is indicated in the specifications that for the aprons we must have $80 \%$ of the 28 day strength.

After 24 hours the target compressive strength is $\mathrm{Rc}_{1}=40.25 \times 0.8=32.2 \mathrm{MPa}$

To achieve this, we opt to use an admixture to boost the concrete strength. The admixture is composed essentially of naphthalene $\mathrm{C} 8 \mathrm{H} 10$.

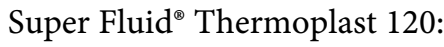

Super-plasticizer, for self-leveling concretes (SCC), water reducer, for better control of concrete slump, for fast high-strength concrete, for obtaining an anticorrosion inhibitor, for a water repellent concrete (@0.55 water/cement ratio), acts as anti-segregation and anti-crack agent, perfect and smooth aesthetic finish of the concrete surface.

With a delay time of up to 90 - 120 minutes.

For the same compositions of Table 8 we add $2.3 \%$ super fluid Thermoplast and increase the cement from $350 \mathrm{~kg}$ to $400 \mathrm{~kg}$.

The results obtained are shown in Table 11.

With a dosage of $350 \mathrm{~kg}$ of cement and $2.3 \%$ of admixture we can't achieve the compressive strength at $24 \mathrm{hrs}$.

However using the same amount of admixture, we increased the cement content to $400 \mathrm{~kg} / \mathrm{m}^{3}$ and the $\mathrm{Rc}_{1}$ of both types of aggregate are greater than $32 \mathrm{MPa}$ or $80 \%$ of the $\mathrm{Rc}_{28}$.

\section{Conclusions}

The objective of this experimental study is to evaluate the substitutional characteristics of basalt kasila group and gneiss of the Archean Man. Standardized geotechnical testing was conducted at the SLRA (Sierra Leone Roads Authority), CSE (Compagnie Sahéliénned' Entreprises) and Unixs (Universal Construction, Chemicals, Commodities, Consulting \& Services) laboratories. 
Table 10. Compressive strength at $\mathrm{Rc}_{7}$ and $\mathrm{Rc}_{28}$.

\begin{tabular}{cccc}
\hline Matrials & $\begin{array}{c}\text { Compressive strength } \\
\mathbf{R c}_{7}(\mathrm{MPa})\end{array}$ & $\begin{array}{c}\text { Compressive strength } \\
\mathrm{Rc}_{28}(\mathrm{MPa})\end{array}$ & Slump (mm) \\
\hline Gneiss & 30 & 40 & 75 \\
Basalt & 34 & 45 & 80 \\
SPECIFICATIONS & & $>34.5 \mathrm{MPa}$ & $50<\mathrm{A}<90$ \\
\hline
\end{tabular}

Table 11. Compressive strength values $\mathrm{Rc}_{1}, \mathrm{Rc}_{7}, \mathrm{Rc}_{28}$.

\begin{tabular}{ccccc}
\hline Materials & $\begin{array}{c}\text { Compressive } \\
\text { Strength } \\
(\mathrm{MPa}) \mathbf{2 4} \mathrm{h}\end{array}$ & $\begin{array}{c}\text { Compressive } \\
\text { Strength Rc7 }(\mathrm{MPa})\end{array}$ & $\begin{array}{c}\text { Compressive } \\
\text { Strength } \mathrm{Rc}_{28} \\
(\mathrm{MPa})\end{array}$ & Slump (mm) \\
\hline Gneiss & 34 & 52 & 57 & 12 \\
Basalt & 35 & 57 & 64 & 14 \\
SPECIFICATIONS & $>32$ & & $>40.25 \mathrm{MPa}$ & $70<\mathrm{A}<150$ \\
\hline
\end{tabular}

The asphalt mix design with gneiss aggregate has good characteristics which meet the technical requirements. But the characteristics of asphalt concrete with basalt aggregates are much better. The idea of increasing $2 \%$ of gneiss filler in the F1 formulation is well justified by the increase in Marshall and Duriez characteristics shown in the F2 mix design. The performance of the F2 mix design has many similarities with those of F4. By adding $2 \%$ of cement to the F2 formulation, we obtain the F3 mix which shows losses in stability (fall up to 1200 $\mathrm{kg}$ ) and in flow. The cement behaves like an excess of filler which has a negative impact on the performance.

The study shows that with an addition of $2 \%$ filler on mix 1 we have an optimal binder content of $5.25 \%$. The justification in adding $2 \%$ filler to the $\mathrm{F} 1$ mixture is demonstrated because the F2 mix is closer to the F4 mix (the Marshall and Duriez characteristics are almost identical): this allows us to use gneiss in place of the F4 basalt mix to continue to produce asphalt concrete without added transportation costs.

Hydraulic concrete mix design by the Dreux-Gorisse method with a cement content of $350 \mathrm{~kg} 42.5 \mathrm{R}$ gives a simple compressive strength at 28 days of 40 $\mathrm{MPa}$ with aggregates of gneiss and $45 \mathrm{MPa}$ with basalt granules. These values are higher than the minimum of $35 \mathrm{MPa}$ required.

A cement content of $400 \mathrm{~kg} 42.5 \mathrm{R}$ with the addition of second-generation additive Super Fluide ${ }^{\circledast}$ Thermoplaste 120 allowed us to achieve $80 \%$ of $\mathrm{Rc}_{28}$ at 24 hours. The compressive strength results obtained at $24 \mathrm{hrs}$ are respectively 34 $\mathrm{MPa}$ and $35 \mathrm{MPa}$. These values are greater than the target value of $32 \mathrm{MPa}$ at 24 hours.

With these results, the study confirms that gneiss can be used as a substitute for basalt to complete the remaining $50 \%$ of the Bandajuma-Mano River project. 


\section{Conflicts of Interest}

The authors declare no conflicts of interest regarding the publication of this paper.

\section{References}

[1] Liégeois, et al. (1991) The Hoggar Swell and Volcanism: Reactivation of the Precambrian Tuareg Shield during Alpine Convergence and West African Cenozoic Volcanism.

[2] Lemoine (1988) Orogenic Processes in West Africa.

[3] The Asphalt Institute (2001) Superpave Mix Design (SP-2). 128 p.

[4] Feybesse, et al. (1990) Transcurrent Tectonics and Polycyclic Evolution in the Lower Proterozoic of Senegal-Mali.

[5] Milesi, J.P., Feybesse, J.L., Ledru, P., Dommanget, A., Ouedraogo, M.F., Marcoux, E., Prost, A.E., Vinchon, C., Sylvain, J.P., Johan, V., Tegyey, M., Calvez, J.Y. and et Lagny, P. (1989)) The Gold Mineralization of West Africa. 497, 3-98.

[6] Frocht (1948) Tensile Fillet Stresses in Loarded Projections.

[7] Bonaquist, R. (2008) NCHRP Report 629: Ruggedness Testing of the Dynamic Modulus and Flow Number Tests with the Simple Performance Tester. Transportation Research Board, Washington, DC, 39 p. https://doi.org/10.17226/14200

[8] Hadjab, H. (2014) The Use of the DREUX-GORISSE Method in the Preparation of Concrete Mixes, an Automatic Approach. Asian Journal of Civil Engineering (BHRC), $15,79-93$. 